\title{
USE AND INTERPRETATION OF THE ANTISTREPTOLYSIN TEST
}

\author{
BY \\ H. S. LAWY \\ Department of Pathology, Grimsby General Hospital
}

Numerous laboratory tests have been devised and used with varying enthusiasm as aids in the diagnosis of rheumatic fever, but the establishment of the intimate relationship between this condition and upper respiratory tract streptococcal infection has directed interest mainly to the demonstration of serological evidence of streptococcal activity in rheumatic subjects. Of the various tests used for this purpose, the antistreptolysin " $O$ ", originally introduced by Todd (1932a, b), has emerged as the most reliable and consistent, but as yet there is no general agreement as to its true value, possibly due to lack of understanding of its interpretation and limitations.

In this laboratory the estimation of antistreptolysin " $O$ " titres (A.S.L.T.) was undertaken, in the first place, as part of a study on rheumatic heart disease in conjunction with the late area cardiologist, Dr. J. W. Brown. However, it rapidly became established in the area as a routine test in the investigation of acute rheumatism and other diverse clinical conditions.

The experience gained from the interpretations of over 4,000 titrations performed during the past 9 years is summarized below.

\section{Material}

The subjects were drawn from general hospitals, from $\vec{\omega}$ the Hull Rheumatic Unit, and from private practice. There were 363 cases of acute rheumatism, 114 of acute $\hat{N}$ nephritis, and 315 others, making a total of 792 (Table I). 을

\section{Methods}

The method described by Hodge and Swift (1933) was used with the following minor modifications:

(1) A locally isolated strain of group A type 1 beta- $\frac{\vec{C}}{\odot}$ haemolytic streptococcus was used in preference $\stackrel{\circ}{\circ}$ to the classical Richards strain as it was a beterer. lysin producer.

(2) Culture medium: Todd-Hewitt's broth as mo\$ fied by Hodge and Swift (1933).

(3) All dilutions were carried out in isotonic buffered saline as recommended by Herbert and $\frac{\circ}{D}$ Todd (1941).

(4) The following simplified serum dilution range $\overrightarrow{\vec{O}}$ was adopted: $50,100,200,300,400,600,800,3$ $1,200,1,600,2,400$.

(5) Red cell suspension: a $2 \cdot 5$ per cent. suspension prepared from pooled human blood obtained from the remains of the normal erythrocyte ${ }_{0}$ sedimentation rate samples was found con- 0 venient and satisfactory. The anticoagulant 3 . used was $3 \cdot 8$ per cent. sodium citrate.

TABLE I

SOURCES OF 792 CASES

\begin{tabular}{|c|c|c|c|c|c|}
\hline \multicolumn{2}{|c|}{ Sources of Cases } & General Hospitals & $\begin{array}{l}\text { Rheumatic Unit, } \\
\text { Kingston General } \\
\text { Hospital, Hull }\end{array}$ & $\begin{array}{c}\text { General } \\
\text { Practitioners }\end{array}$ & Total \\
\hline \multirow[t]{2}{*}{ Condition } & 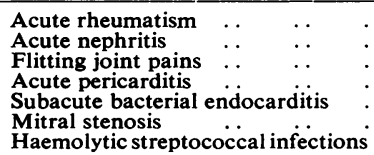 & $\begin{array}{r}203 \\
75 \\
31 \\
14 \\
10 \\
45 \\
39\end{array}$ & $\begin{array}{r}117 \\
28 \\
8 \\
9 \\
11 \\
114 \\
0\end{array}$ & $\begin{array}{r}43 \\
11 \\
14 \\
2 \\
0 \\
18 \\
0\end{array}$ & $\begin{array}{r}363 \\
114 \\
53 \\
25 \\
21 \\
177 \\
39\end{array}$ \\
\hline & $\begin{array}{lll}. . & . .\end{array}$ & 417 & 287 & 88 & 792 \\
\hline
\end{tabular}


(6) Standard antistreptolysin, supplied by the Standard Serum Laboratories, Carshalton, was used throughout for the titration and standardization of the lysin.

(7) The antistreptolysin titre (A.S.L.T.) was expressed in Todd units, namely the reciprocal of the serum dilution which exactly neutralizes one unit standard lysin.

\section{Results}

The results obtained from 792 patients were analysed. In most cases three to four titrations were carried out and in many several titrations were performed over a period of many months. The 275 controls were tested only once.

Controls. - In this, as in all serological tests, what matters most is the controls. For this reason, the sera of 275 normal persons with no known recent streptococcal infection were examined. These con- trols were drawn mainly from the nursing and other hospital staff including laboratory technicians. Those in the younger age group, however, were mainly traumatic cases and also included other carefully selected hospital patients. The results are shown in Table II.

It will be seen that 88 per cent. gave titres of less than 200 Todd units $/ \mathrm{ml}$. and 74 per cent. of 100 or less. The average titre was lower at both extremes of age.

Acute Rheumatism and Acute Nephritis. - The sera of 363 patients with acute rheumatism and 114 with acute nephritis (Ellis, Type 1) were examined. The results are shown in Table III.

It will be seen that the results in both conditions were similar, about 80 per cent. of patients giving titres of 200 Todd units or more. This was virtually a reversal of the result obtained with the controls.

TABLE II

ANTISTREPTOLYSIN TITRE DISTRIBUTION IN 275 HEALTHY CONTROLS

\begin{tabular}{|c|c|c|c|c|c|c|c|c|c|}
\hline \multirow{2}{*}{\multicolumn{3}{|c|}{$\begin{array}{c}\text { Antistreptolysin } \\
\text { Titres } \\
\text { (Todd Units) }\end{array}$}} & \multirow[b]{2}{*}{ 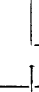 } & \multicolumn{6}{|c|}{ Percentage Distribution by Age Group (yrs) } \\
\hline & & & & $1-10$ & $11-20$ & $21-40$ & $41-60$ & Over 60 & All Ages \\
\hline Nil .. & .. & . & $\ldots$ & 50 & $40 \cdot 9$ & $35 \cdot 7$ & $46 \cdot 8$ & $52 \cdot 8$ & $43 \cdot 6$ \\
\hline $100 \ldots$ & .. & .. & .. & $35 \cdot 3$ & $27 \cdot 3$ & $32 \cdot 2$ & $28 \cdot 5$ & $30 \cdot 5$ & $30 \cdot 6$ \\
\hline $150 \ldots$ & . & . & .. & $11 \cdot 8$ & $15 \cdot 9$ & $16 \cdot 6$ & $11 \cdot 7$ & $11 \cdot 1$ & $13 \cdot 8$ \\
\hline $200 \ldots$ & .. & .. & .. & $2 \cdot 9$ & $11 \cdot 4$ & $10 \cdot 7$ & $7 \cdot 8$ & $2 \cdot 8$ & $8 \cdot 0$ \\
\hline Over 200 & $\ldots$ & $\ldots$ & .. & - & $4 \cdot 5$ & $4 \cdot 8$ & $5 \cdot 2$ & $2 \cdot 8$ & $4 \cdot 0$ \\
\hline Total Con & trols & .. & $\ldots$ & 34 & 44 & 84 & 77 & 36 & 275 \\
\hline
\end{tabular}

TABLE III

ANTISTREPTOLYSIN TITRE DISTRIBUTION IN VARIOUS CLINICAL CONDITIONS

\begin{tabular}{|c|c|c|c|c|c|c|c|}
\hline \multirow{3}{*}{\multicolumn{4}{|c|}{ Condition }} & \multirow{3}{*}{ All Cases } & \multicolumn{3}{|c|}{ Percentage Reactors in each Group } \\
\hline & & & & & \multicolumn{2}{|c|}{ Reactors } & \multirow{2}{*}{$\begin{array}{c}\text { Non-Reactors } \\
\text { Titre } \\
\text { (Under } 200 \text { units } / \mathrm{ml} \text {.) }\end{array}$} \\
\hline & & & & & $\begin{array}{c}\text { High Titre } \\
\text { (Over } 400 \text { units } / \mathrm{ml} \text {.) }\end{array}$ & $\begin{array}{c}\text { Low Titre } \\
\text { (200-400 units } / \mathrm{ml} .)\end{array}$ & \\
\hline \multirow{2}{*}{ Acute Rheumatism } & Over 1 & years Old & .. & 308 & $47 \cdot 3$ & $36 \cdot 2$ & $16 \cdot 5$ \\
\hline & 10 year & and Under & .. & 55 & $41 \cdot 8$ & $36 \cdot 3$ & $21 \cdot 8$ \\
\hline \multirow{2}{*}{ Acute Nephritis } & Over 10 & years Old & .. & 74 & $39 \cdot 2$ & $35 \cdot 2$ & $25 \cdot 6$ \\
\hline & 10 year & and Under & $\cdots$ & 40 & $52 \cdot 5$ & 25 & $22 \cdot 5$ \\
\hline Flitting Joint Pains & . & $\cdots$ & . & 53 & $35 \cdot 8$ & $22 \cdot 7$ & $41 \cdot 5$ \\
\hline Acute Pericarditis & . & .. & .. & 25 & 28 & 28 & 44 \\
\hline \multicolumn{2}{|c|}{ Subacute Bacterial Endocarditis } & . & .. & 21 & $4 \cdot 8$ & 19 & $76 \cdot 3$ \\
\hline Mitral Stenosis & .. & . & .. & 177 & $3 \cdot 4$ & $25 \cdot 5$ & $71 \cdot 1$ \\
\hline \multicolumn{3}{|c|}{ Active Haemolytic Streptococcal Infections } & . & 39 & $35 \cdot 9$ & $43 \cdot 6$ & $20 \cdot 5$ \\
\hline \multicolumn{2}{|c|}{ Total } & . & .. & 792 & & & \\
\hline
\end{tabular}


In both diseases titres of 800 to 1,200 units were commonly found, and two cases of acute nephritis and one of acute rheumatism showed the very high titre of 10,000 units $/ \mathrm{ml}$. No statistically significant difference was found between the results in children and in adults, but few children were examined.

Other Illnesses (Table III and Fig. 1).-In 39 cases of known streptococcal infection (mainly puerperal pyrexia and scarlet fever) where haemolytic streptococci (group A with very few group C or G) had been isolated, a similar pattern of distribution of reactivity was found.

In 53 cases of "flitting joint pains" and in 25 cases of acute pericarditis about 50 per cent. were reactors.

177 cases of mitral stenosis and 21 cases of subacute bacterial endocarditis showed a similar pattern, with a low percentage of positives consisting mainly of low reactors.

Fig. 1 compares the A.S.L.T.s in the normal controls with those in persons with various diseases.

\section{Antistreptolysin Response in Rheumatic Fever}

The A.S.L.T. in patients with rheumatic fever usually shows a special pattern with an initial lag and a slow rise to a maximum in 5 to 6 weeks (after the initial sore throat), slowly tapering off over a period of several weeks. Cases with complications (e.g. carditis or relapse) show a striking see-saw pattern (Coburn, 1936; Rothbard, Watson, Swift, and Wilson, 1948).

The drop of the antistreptolysin titre almost always lags behind that of the erythrocyte sedimentation rate and in many cases the A.S.L.T. continues to rise while the E.S.R. is falling.

\section{Case Notes}

Fig. 2 (opposite) shows a typical sequence of events in an uncomplicated "monocyclic" case of rheumatic fever, in a girl aged 7 years with a history of joint pains and pyrexia of 4 to 5 days' duration when first seen by her doctor. She had complained of sore throat 3 weeks before the onset of joint pains. Her response to salicylate therapy was excellent and she made an uneventful recovery.

Fig. 3 (opposite) shows a typical course in a case of rheumatic fever of the relapsing or "polycyclic" type, in a girl aged 11 years, who had her first relapse during her initial stay in hospital. She was kept under observation as an out-patient for a considerable time, mainly because of
(I)

(2)

(3)

(4)

(5)

(6)

(7)

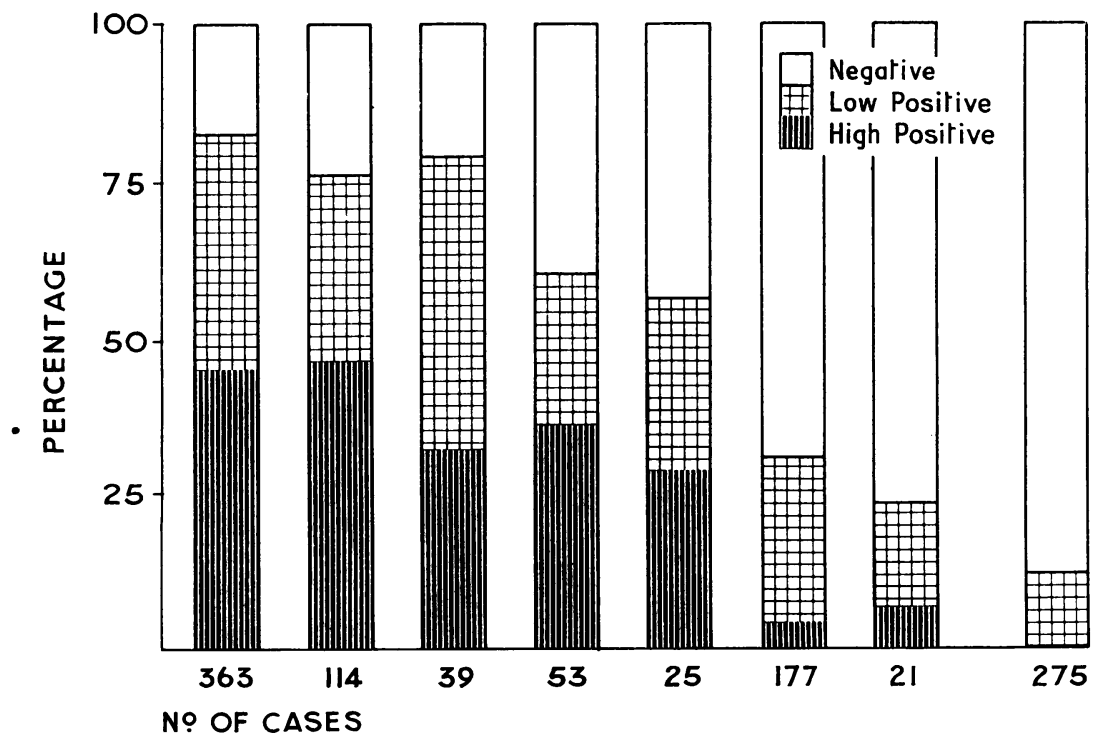

(8)

(I) Rheumatic fever

(2) Acute nephritis

(3) Haemolytic streptococcal infections

(4) Flitting joint pains

(5) Acute pericarditis

(6) Mitral stenosis

(7) Subacute bacterial endocarditis

(8) Normal controls

Fig. 1.-Antistreptolysin titres in normal controls (one titration) and in patients with various diseases (three titrations or more). 
$\underset{\text { C-Reactive Protein }+}{\text { Joint Poins }++}+\overline{+}+\overline{+} \quad+$

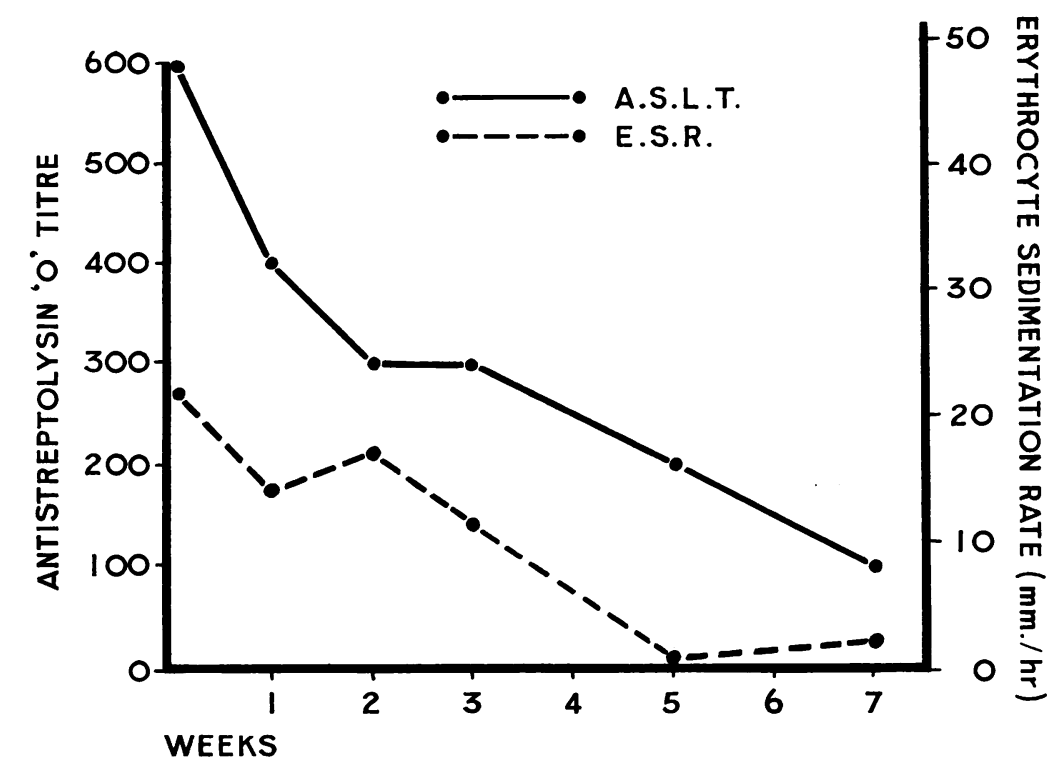

Fig. 2.-Antistreptolysin titre pattern in an attack of rheumatic fever with no complications.

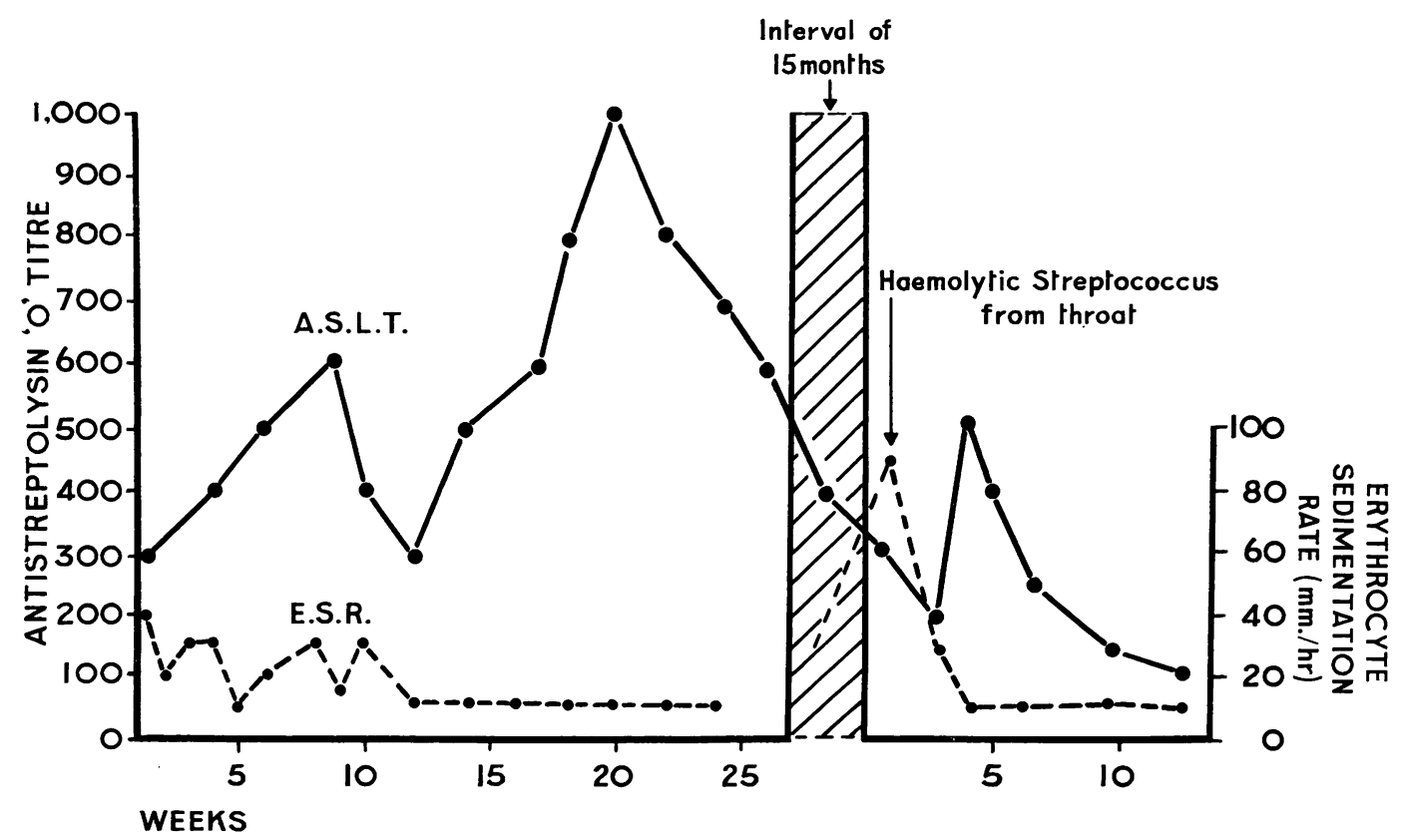

Fig. 3.-Case of rheumatic fever showing typical accelerated massive antistreptolysin titre response during an initial relapse and depressed response following the administration of penicillin during a second relapse. 
the persistent elevation of the antistreptolysin titre, and was eventually re-admitted 15 months later with sore throat, joint pains, and active carditis. On this occasion a haemolytic streptococcus was isolated from the throat, and she was treated with penicillin.

\section{Discussion}

To interpret the results of the test, it is essential to know the normal antistreptolysin level. Whilst most workers agree that 200 Todd units $/ \mathrm{ml}$. or above is abnormal (Rantz, Randall, and Rantz, 1948; Rantz, 1955), many have considered this figure or even 250 units as the upper limit of normality (Wood and McCarty, 1954; Hollinger, 1953).

The results of the present survey support the former view. The fact that about 12 per cent. of the normal population sampled showed a titre of 200 and over is probably due to the presence of subclinical streptococcal infection of the upper respiratory tract.

Nevertheless, the difficulty of defining the demarcation line between normal and abnormal must be regarded as one of the limitations of the test. It is therefore necessary to seek evidence of a significant rise or fall in titre in all cases, especially those with initial low levels. The most that can be said about a single finding of a high titre is that it provides supportive evidence in clinically established cases.

Another limitation of the test is the fact that only 80 to 85 per cent. of cases of clinically established rheumatic fever and acute nephritis will show a significant antistreptolysin response (Table II); even in cases of active streptococcal infection 20 per cent. of the subjects failed to develop this antibody. This, however, need not detract from the value of the test if the following points are borne in mind:

(1) The A.S.L.T. is not a test for rheumatic fever or acute nephritis, but a test for evidence of activity of Lancefield's Group A streptococci (or occasionally Groups C and G). As such, the intensity of the response necessarily varies with the duration of activity of the stimulus. Therefore the duration of the antecedent sore throat, the type of treatment then administered, and a history of previous attacks are important factors. While serological evidence may be detected during the second week after the infection, the maximum response does not generally develop before 5 or 6 weeks and may be partially suppressed by antibiotic therapy (Kilbourne and Loge, 1948). On the other hand, during a relapse, the titre rises much more quickly and to higher levels.

(2) Different strains of Group A streptococci vary greatly in their antigenic capacity (Lancefield and Stuart, 1944; Herbert and Todd, 1944).
(3) The antibody response mechanism in certain individuals is sluggish (Wilson and Miles, 1955).

It should also be recalled that Group A streptococci produce an extraordinary variety of extracellular substances, several of which (including streptolysin, hyaluronidase, and streptokinase) stimulate the production of readily measurable antibodies. Some investigators, by testing for a sufficient number of these antibodies, have been able to demonstrate that approximately 100 per cent. of their rheumatic fever cases show unequivocal response to at least one of these streptococcal components (Rothbard and others, 1948).

These other tests, however, are difficult to perform and to standardize, and remain as yet in the domain of pure research, while the antistreptolysin has proved accurate and reliable and appears to be the one likely to yield most information if its limitations are well understood.

It is therefore important to emphasize the following points:

(1) No matter what the initial A.S.L.T. may be, the demonstration of a rise in titre should be sought in all cases with initial low levels. At least two to three repeated titrations at not less than 1-week intervals may be necessary to establish the presence or absence of a significant response A four-fold or two-tube rise in a straig庳 doubling dilution is accepted as significant.

(2) Although the absence of a rise in titre does now necessarily exclude recent streptococcal infection, a persistent titre of 50 or less is almost certain $\frac{\circ}{D}$ evidence against rheumatic fever or acute $\varrho$ glomerulo-nephritis, and such a result at least $\overrightarrow{\vec{O}}$ merits a critical re-assessment of the clinical 3 diagnosis (Wood and McCarty, 1954). On the other hand, the failure of the A.S.L.T. to show a significant drop during late convalescence from acute rheumatism strongly indicates continued streptococcal activity and with it the possibility of relapse.

The antistreptolysin test can be of help to the clinician in a variety of conditions such as "flitting joint pains", where the diagnosis is notoriously 윽 difficult or in cases of acute pericarditis where $D$ frequently no evidence of rheumatic aetiology is obtained, although only about 50 per cent. of them $\bar{N}$ show a significant titre.

In mitral stenosis and sub-acute bacterial endo- $\mathrm{O}$ carditis the percentage of positive reactors is quite $\mathrm{N}$ low as would be expected on clinical grounds. However, these include the occasional case in which 0 the establishment or exclusion of rheumatic activity $\frac{\bar{\Phi}}{\Phi}$ is very important.

In a limited series of cases of mitral stenosis, about $\square$ one-third showed Aschoff's bodies and correlated 
closely with a positive A.S.L.T. finding (Brown, 1958). There is also some evidence that patients with high-titre antibodies are more prone to develop the post-valvotomy syndrome (Din, 1958); some clinicians in this area now consider a raised A.S.L.T. sufficient evidence of incipient carditis to delay valvotomy until it subsides.

\section{Summary}

(1) An analysis of the results of over 4,000 antistreptolysin titrations (792 cases) is given. Significant titres (200 units/ml. or more) were obtained in 80 to 85 per cent. of cases of acute rheumatism, acute nephritis, and proved haemolytic streptococcal infections.

(2) The limitations of the test arise from the difficulty of defining normal and abnormal antistreptolysin levels and from the failure of some patients to react. These points are discussed.

(3) The importance is stressed of repeating titrations in order to establish a significant serological response.

(4) The usefulness of the test in conditions other than acute rheumatism is discussed.

I am indebted to Professor C. P. Beattie and Dr. J. M. Johnstone for criticism and discussion and to Dr. L. M. Gerlis for help in many ways.

\section{REFERENCES}

Brown, J. W. (1958). (Late Area Cardiologist, Sheffield Hospital Board.) Personal communication

Coburn, A. F. (1936). Lancet, 2, 1025. Hospital, Hull.) Personal communication.

Herbert, D., and Todd, E. W. (1941). Biochem. J., 35, 1124

Herbert, (1944). Brit. J. exp. Path., 25, 242.

Hodge, B. E., and Swift, H. F. (1933). J. exp. Med., 58, 277

Hollinger, N. F. (1953). Amer. J. publ. Hith, 43, 561 .

Kilbourne, E. D., and Loge, J. P. (1948). J. clin. Invest., 27, 418.

Lancefield, R. C., and Stewart, W. A. (1944). J. exp. Med., 79, 79.
Rantz, L. A. (1955). Med. Clin. N. Amer., 39, No. 2, 339

, Randall, E., and Rantz, H. H. (1948). Amer. J. Med., 5, 3. Rothbard, S., Watson, R. F., Swift, H. F., and Wilson, A. T. (1948) Arch. intern. Med., 82, 229.

Todd, E. W. (1932a). J. exp. Med., 55, 267.

- (1932b). Brit.J. exp. Path., 13, 248

Wilson, G. S., and Miles, A. A. (1955). "Topley and Wilson's Principles of Bacteriology and Immunity", 4th ed., vol. 2, chap. 42 and 49 . Arnold, London.

Wood, H. F., and McCarty, M. (1954). Amer. J. Med., 17, 768.

\section{Application et interpretation de la réaction a l'antistreptolysine \\ RÉSUMÉ}

(1) On présente une analyse des résultats de plus de 4000 déterminations de antistreptolysine (792 cas). Des titres significatifs (200 unités par c.c. ou plus) furent obtenus dans 80 à 85 pour cent des cas de rhumatisme aigu, nephrite aiguë et dans des cas d'infection confirmée par le streptocoque hémolytique.

(2) Les limitations de la réaction viennent de la difficulté de définir les taux normaux et pathologiques de l'antistreptolysine et du fait que certains malades n'y réagissent pas. On discute ces points.

(3) On souligne l'importance des dosages répétés pour obtenir des réponses sérologiques significatives.

(4) On discute l'utilité de la réaction dans des maladies distinctes du rhumatisme aigu.

Uso e interpretación del test de la antiestreptolisina Sumario

(1) Se da un análisis de los resultados de más de 4,000 determinaciones de antistreptolisina (792 casos). Títulos significativos (200 unidades por c.c. o más) fueron obtenidos en el 80 al 85 por ciento de los casos de reumatismo agudo, nefritis aguda y en casos comprobados de infección por estreptococo hemolítico.

(2) Las limitaciones del test nacen de la dificultad de definir los niveles normal y patológico de antistreptolisina y del fallo de ciertos enfermos en reaccionar. Son discutidos estos puntos.

(3) Se insiste sobre la importancia de repetir las titulaciones en orden a establecer una respuesta serológica significativa.

(4) Se discute la utilidad de la prueba en enfermedades distintas al reumatismo agudo. 